\title{
Effects of Intra-Set Rest on Morphological Variables, Maximal Strength and Jump Performance in University Students
}

\author{
Efectos del Descanso Intra-Serie sobre Variables Morfológicas, \\ Fuerza Máxima y Saltabilidad en Estudiantes Universitarios
}

Pablo Aravena-Sagardia ${ }^{1}$; Alán García-Sandoval ${ }^{1}$; Mauricio Barramuño²; Tomás Herrera-Valenzuela ${ }^{3,4}$; Braulio Henrique Magnani Branco $^{5}$; Eduardo Guzmán-Muñoz ${ }^{6}$; Antonio López-Fuenzalida ${ }^{8}$; Enrique Cerda Vega ${ }^{7,8}$ \& Pablo Valdés-Badilla $^{1}$

ARAVENA-SAGARDIA, P.; GARCÍA-SANDOVAL, A.; BARRAMUÑO, M.; HERRERA-VALENZUELA, T.; MAGNANI, B. B. H.; GUZMÁN-MUÑOZ, E.; LÓPEZ-FUENZALIDA, A.; CERDA, V. E. \& VALDÉS-BADILLA, P. Effects of intra-set rest on morphological variables, maximal strength and jump performance in university students. Int. J. Morphol., 39(1):274-281, 2021.

SUMMARY: The appropriate dosage of resistance training could promote physical and physiological adaptations and decrease injuries. The aim of the study was to analyze the effects of the different intra-set rest after eight weeks of resistance training on morphological variables, maximal strength, and jump performance in physically active university students. Twenty-five students (15 men and 10 women) were randomized by sex and distributed in Control Group $(\mathrm{CG})(\mathrm{n}=8)$ with rest only at the end of the series; Experimental Group 1 (EG1) $(\mathrm{n}=9)$ with an intra-set rest of $30 \mathrm{~s}$, and Experimental Group 2 (EG2) (n=8) with four intra-set rest of $10 \mathrm{~s}$. Morphological variables [body weight, bipedal height, body mass index (BMI), fat mass and muscle mass], maximum upper body strength (bench press and military press), lower body strength [parallel squat $\left(45^{\circ}\right)$ and deadlift], as well as countermovement jump (CMJ) were measured. All three groups obtained a significant increase $(p<0.01)$ in body weight and BMI, as well as an essential reduction $(p<0.01)$ of fat mass. Muscle mass increased significantly $(\mathrm{p}<0.01)$ for both CG and EG1. Maximum upper- and lower-body strength increased considerably ( $\mathrm{p}<0.05)$ across all three groups and for all exercises, while the CMJ notably increased for CG and EG1. There are no significant changes between the different intra-set rest, when using the same volume, intensity, and total recovery time during the exercise series ( $p>0.05$ ); thereby, there is an equivalent increase in muscle mass, maximal strength, jump performance, and a fat mass reduction.

KEY WORDS: Anthropometry; Muscle strength; Physical exercise; Strength training.

\section{INTRODUCTION}

Practicing continuous physical activity (PA) has several health benefits, including a reduced risk of developing cardiovascular diseases, type 2 diabetes mellitus, hypertension, high cholesterol, and certain types of cancer (Ministerio de Salud, 2017). Besides, a systematized PA can strengthen physical and physiological aspects through programs focused on cardiorespiratory capacity (Goessler \& Polito, 2013) and resistance training (Tufano et al., 2017). Also, workouts based on resistance training promote the increase of testosterone, an accumulation of the growth hormone, the release of cortisol, and also regulate blood lactate concentration (Oliver et al., 2015; Suchomel et al.,
2016; Mora-Custodio et al., 2018; García-Ramos et al., 2020).

Furthermore, dosing and appropriately prescribing resistance training exercises promote metabolic adaptations and reduce the risk of injury in people (Schoenfeld, 2010; Latella et al., 2019). The dosage recommendations for resistance training exercises in adults indicate an intensity ranging from $70 \%$ to $85 \%$ of a one-repetition maximum (1RM) for muscular hypertrophy (Garber et al., 2011), considering a volume between 3 and 5 sets per exercise with 6 to 12 repetitions per set (Schoenfeld et al., 2016), and rest

\footnotetext{
${ }^{1}$ Physical Education Pedagogy, Faculty of Education. Universidad Autónoma de Chile, Temuco, Chile.

${ }^{2}$ Kinesiology Career, Faculty of Health Sciences. Universidad Autónoma de Chile, Temuco, Chile.

${ }^{3}$ School of Sport Sciences and Physical Activity, Faculty of Health. Universidad Santo Tomás, UST, Chile.

${ }^{4}$ Laboratory of Physical Activity, Sports and Health Sciences, Faculty of Medical Sciences. Universidad de Santiago de Chile.

${ }^{5}$ Graduate Program in Health Promotion. Centro Universitário de Maringá (UniCesumar), Maringá, PR, Brazil.

${ }^{6}$ Kinesiology school, Faculty of Health. Universidad Santo Tomás, Chile.

${ }^{7}$ Kinesiology career, Department of Health Science, Faculty of Medicine. Pontificia Universidad Católica de Chile.

${ }^{8}$ Physical Education and Health Pedagogy, Faculty of Education. Pontificia Universidad Católica de Chile.
} 
ARAVENA-SAGARDIA, P.; GARCÍA-SANDOVAL, A.; BARRAMUÑO, M.; HERRERA-VALENZUELA, T.; MAGNANI, B. B. H.; GUZMÁN-MUÑOZ, E.; LÓPEZ-FUENZALIDA, A.; CERDA, V. E. \& VALDÉS-BADILLA, P. Effects of intra-set rest on morphological variables, maximal strength and jump performance in university students. Int. J. Morphol., 39(1):274-281, 2021.

between sets ranging from 60 to 180 seconds (Garber et al.; Schoenfeld et al.). However, short-term recovery periods within the (intra-set) series have been reported to favor an increase in metabolic stress, allowing a more significant adaptation for the stimulus (Grgic et al., 2017). Intra-set rest is recovery within the series without altering the total programmed rest. These rest usually vary from 6 to 45 seconds and are interspersed in groups of 2 to 5 repetitions (Haff et al., 2008; Latella et al.; Tufano et al., 2017).

Hence, new resistance training protocols have emerged, including the intra-set rest (called cluster sets), a methodology which has shown more exceptional individual performance, avoiding the exhaustion produced by traditional training (Hardee et al., 2012; Oliver et al., 2015; Tufano et al., 2017). Studies using cluster sets have shown a reduction in muscle fatigue and lower levels of strength, speed, and power loss when performing the exercises (Haff et al.; Hardee et al.; Oliver et al., 2015; Tufano et al., 2017, 2019). Likewise, they provide greater neuromuscular adaptations to maintain the work intensity, such as the mechanic movement, thus avoiding overtraining (Nóbrega \& Libardi, 2016; Latella et al.).
In this context, intra-set rest are believed to favor the reduction of muscle fatigue, helping to keep the strength and speed of exercise execution, and providing training with a similar intensity during the whole session (García-Ramos et al.; Oliver et al., 2015). Although there is enough scientific evidence outlining the recommendations on the exercise periodization of resistance training (Grgic et al.; Latella et al.; Tufano et al., 2017, 2019), there are still few studies addressing the optimal intra-set rest periods undertaken to encourage the growth of strength and muscle mass. Based on the literature (Iglesias-Soler et al., 2016; Oliver et al., 2015; Tufano et al., 2017, 2019; García-Ramos et al.), intraset rest intervals are hypothesized to produce more significant changes in morphological variables, such as an increase in peak force and jump performance, rather than completing rest intervals at the end of the series. For that reason, this study aims to analyze the effects of the different intra-set rest after eight-week of resistance training on morphological variables, maximal strength, and jump performance in physically active university students.

\section{MATERALAND METHOD}

Research design. An experimental design was used, with parallel groups and repeated measures. The participants were selected through a proportional and random sampling (https:// www.randomizer.org), and organized by gender in a) Control Group (CG), who had a rest at the end of the 120 s series; b) Experimental Group 1 (EG1) with an intra-set rest of $30 \mathrm{~s}$ (after 5 repetitions) plus one rest at the end of the $90 \mathrm{~s}$ series; and c) Experimental Group 2 (EG2) with four intra-set rest of $10 \mathrm{~s}$ (after two repetitions) and a rest at the end of the $80 \mathrm{~s}$ series (Fig. 1).

Participants. The population included all first-year students enrolled in the Physical Education Pedagogy from a Chilean University $(\mathrm{n}=34)$. On average, they were $19 \pm 1.2$ years old, body mass $67.6 \pm 8.6 \mathrm{~kg}$, had a bipedal height of $1.69 \pm 0.1 \mathrm{~cm}$, and a body mass index (BMI) of $23.6 \pm 1.9$

Fig. 1. Flow chart of the process followed in the research. 
ARAVENA-SAGARDIA, P.; GARCÍA-SANDOVAL, A.; BARRAMUÑO, M.; HERRERA-VALENZUELA, T.; MAGNANI, B. B. H.; GUZMÁN-MUÑOZ, E.; LÓPEZ-FUENZALIDA, A.; CERDA, V. E. \& VALDÉS-BADILLA, P. Effects of intra-set rest on morphological variables, maximal strength and jump performance in university students. Int. J. Morphol., 39(1):274-281, 2021.

$\mathrm{kg} / \mathrm{m}^{2}$. The following inclusion criteria were considered: a) be > 18 years old; b) be physically active according to the criteria of the American College of Sports Medicine and the American Heart Association (Haskell et al., 2007; Garber et al.); that is to say, practicing more than $150 \mathrm{~min}$ of moderate or 75 min of vigorous PA weekly; c) no having taken part in resistance training programs for the last six months prior the intervention. The exclusion criteria were: a) no musculoskeletal injuries for the last three months, b) no use of food supplements (creatine, amino acids, protein shakes, pre-workouts, among others), c) participation in at least $85 \%$ of the intervention sessions. The CG was made up of 12 participants ( 7 men and 4 women), the EG1 had 11 participants ( 7 men and 4 women), and the EG2 had 11 participants ( 6 men and 4 women). After eight weeks of intervention, nine students were excluded from the study as they did not meet the minimum session attendance, with no injuries recorded. Finally, the sample for the statistical analyses was eight students for the CG, nine students for the EG1, and eight students for the EG2. Figure 1 shows the graphic description of the participants' randomization process.

All students received information regarding the research scope and signed an informed consent form authorizing the use of information for scientific purposes. This research protocol was reviewed and approved by the Scientific Ethics Committee ( $N^{\circ}$ 68-18) of Universidad Autónoma de Chile and developed following the Helsinki Declaration (World Medical Association, 2019).

\section{Measurements}

Morphologic variables. The following measurements were registered to identify the study variables: a) total body weight in $\mathrm{kg}$ with an electronic scale (Scale-tronix, USA; accuracy: $0.1 \mathrm{~kg}$ ); b) bipedal height in $\mathrm{cm}$ with a stadiometer (Seca 220, Germany; accuracy: $0.1 \mathrm{~cm}$ ); c) skinfolds in mm with a skinfold calibrator (Harpenden, England; accuracy: 0.2 $\mathrm{mm})$, used for the tricipital, subscapular, supraspinal, abdominal, frontal thigh, and medial calf folds; d) body perimeters in cm with measuring tape (Seca 201, Germany; accuracy: $0.1 \mathrm{~cm}$ ) by registering the value of the relaxed arm, maximum forearm, transverse chest, maximum thigh, medial thigh, and maximum calf. All measurements were made following the recommendations of the International Society for the Advancement of Kinanthropometry (ISAK) (Marfell-Jones et al., 2012) through an ISAK level II anthropometrist (technical measurement error: $0.8 \%$ for all assessed variables).

Using the indirect penta compartmental fractionation technique proposed by Ross \& Kerr (1993), the components of the muscle and fat mass body composition were determined with the same anthropometric pre- and post-intervention model. Moreover, the BMI was calculated by dividing the body weight by the bipedal height squared $\left(\mathrm{kg} / \mathrm{m}^{2}\right)$.

\section{Maximal strength}

The upper body was assessed through a 1RM using the bench press and military press and the lower body with a parallel squat $\left(45^{\circ}\right)$ and deadlift (the exercises are explained in the intervention section). The 1RM assessment is highly reliable to measure trained people (Ritti-Dias et al., 2011). The following procedure was implemented: a) a series of five high-speed repetitions with an Olympic bar $(20 \mathrm{~kg})$ and a $20 \mathrm{~s}$ rest; b) then three series of five repetitions with a rest between series of 2 min, gradually increasing the weight; c) followed by a controlled-speed repetition, with a rest of 3 to 5 min until reaching 1RM. The assessments were distributed in one session to obtain $1 \mathrm{RM}$ for the bench press and the parallel squat $\left(45^{\circ}\right)$, and after 48 hours, the 1RM was measured for the military press and deadlift.

Jump performamce. A force platform was used for the countermovement jump test (CMJ) (Art Oficio, PF-4000/ 50; Chile). During the test execution, each participant was placed in a standing position, with feet parallel to shoulder width, knees extended, and hands placed on the waist. After performing a quick downward movement, they flexed their knees and hips, followed by a quick leg extension, resulting in a maximum vertical jump. The participants performed three CMJ repetitions with a rest of 2 min between each one; subsequent analyses considered the maximum height of the best attempt (Bosco et al., 1983).

Intervention. During the first session, the students were interviewed and informed about the research scopes. On the second session, they were instructed about the correct execution of the exercises considered for the intervention; to this end, they previously performed a 10-min warm-up on a treadmill at a continuous speed of $8 \mathrm{~km} / \mathrm{h}$ (Sportsartt650me, USA), to then execute the resistance training programmed exercises (bench press, military press, parallel squat $\left(45^{\circ}\right)$ and deadlift).

After the initial evaluations, all participated in the eight-week resistance training intervention, which were distributed in two weekly sessions (16 sessions with a 48hour recovery period between each one), and performed the following exercises: a) bench press: in a supine position on a bench press stretcher, they performed elbow flexextensions by bringing an Olympic bar to the chest, 
ARAVENA-SAGARDIA, P.; GARCÍA-SANDOVAL, A.; BARRAMUÑO, M.; HERRERA-VALENZUELA, T.; MAGNANI, B. B. H.; GUZMÁN-MUÑOZ, E.; LÓPEZ-FUENZALIDA, A.; CERDA, V. E. \& VALDÉS-BADILLA, P. Effects of intra-set rest on morphological variables, maximal strength and jump performance in university students. Int. J. Morphol., 39(1):274-281, 2021.

followed by an elbow extension $\left(180^{\circ}\right)$; b) military press: in a standing position they performed an elbow and shoulder flexo-extension with a straight torso, using an Olympic bar; c) parallel squat $\left(45^{\circ}\right)$ : in a standing position, they performed a knee flexion of over $45^{\circ}$ with a straight torso, and parallel feet and knees, and then performed a full knee extension; d) deadlift: in a standing position, they performed a hip flexion-extension with slight knee flexion and a straight torso using an Olympic bar. All students executed a resistance training program equivalent in volume, intensity, and total recovery time, with four sets and ten repetitions per set during the entire intervention. The program increased the load percentage every two weeks, starting with $70 \%$ of 1RM per exercise and ending at $85 \%$. These values were individually planned according to the result obtained for the initial assessment. Figure 2 shows the intervention summary.

Statistical analysis. The SPSS software (Statistical Package for the Social Sciences) version 25.0 was used for data analysis. Variables were tested using the Shapiro-Wilk normality test, the Levene variance homogeneity test, and descriptive analysis to calculate the arithmetic mean, standard deviation, and the minimum and maximum values. Pre- and post-intervention differences in groups were made with the Student t-test when variables were regular, and with Wilcoxon when they were not. Comparisons between groups were made using a two-way analysis of variance (ANOVA) with repeated measures considering the time (before vs. after the intervention) and group (CG vs. EG1 vs. EG2), with the corresponding all pairwise post hoc comparison with Bonferroni corrections. The effect size was determined with Cohen's d (Cohen, 1992), estimating a small (between $0.20-0.49)$, moderate $(0.50-0.79)$ or strong $(>0,80)$, effect; for all cases, a significance level of $\mathrm{p}<0.05$ was established.

\section{RESULTS}

Table I shows changes in morphological variables. All three groups obtained a significant increase $(p<0.01)$ in body weight and BMI, as well as a significant reduction $(\mathrm{p}<0.01)$ of fat mass. The muscle mass percentage increased in all three groups of students leading to significant changes $(\mathrm{p}<0.01)$ for $\mathrm{CG}$ and $\mathrm{EG} 1$. Multiple comparisons did not show significant differences between groups.

Table II shows the changes in maximal strength and jump performance. A significant increase $(\mathrm{p}<0.05)$ in peak force was seen for all exercises (bench press, military press, parallel squat $\left(45^{\circ}\right)$, and deadlift) in all three groups. The $\mathrm{CMJ}$ reported an increase in the maximum height for all three groups, with significant changes $(p<0.01)$ in the $C G$ and the EG1. Multiple comparisons did not show significant differences between groups.

Fig. 2. Research Design. CG: control group; EG1: experimental group 1; EG2: experimental group 2; 1RM: one-repetition maximum.

\begin{tabular}{|c|c|c|c|}
\hline Adaptation & Pre-test & Intervention & Post-test \\
\hline $\begin{array}{l}\begin{array}{l}\text { Learning } \\
\text { from the: }\end{array} \\
\text { Bench press } \\
\text { Military Press } \\
\text { Parallel Squat } \\
\text { Deadlift }\end{array}$ & $\begin{array}{l}\text { Session 1: } \\
\text { Anthropometry } \\
\text { Jump } \\
\text { performance } \\
\text { (CMJ) } \\
\text { Session 2: } \\
\text { I RM bench } \\
\text { Press and } \\
\text { Parallel Squat } \\
\left(45^{\circ}\right) \\
\text { Session 3: } \\
\text { I RM Military } \\
\text { Press and } \\
\text { Deadlift }\end{array}$ & 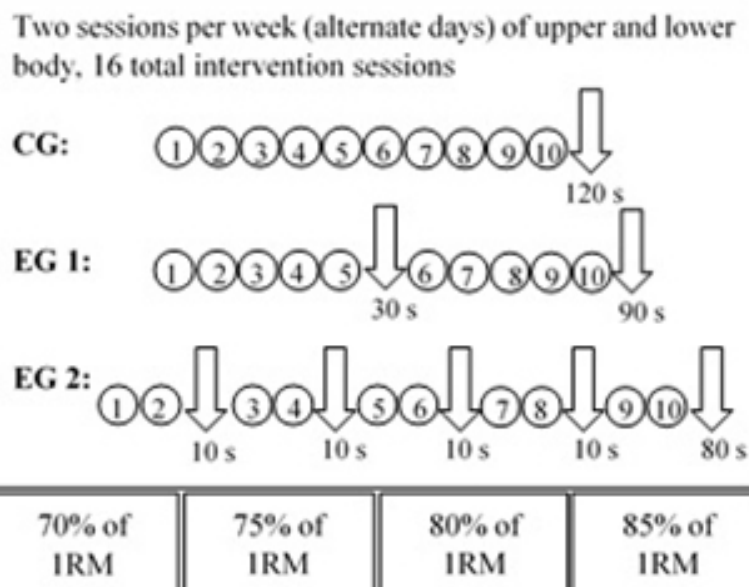 & $\begin{array}{l}\text { Session 1: } \\
\text { Anthropometry } \\
\text { Jump } \\
\text { performance } \\
\text { (CMJ) } \\
\text { Session 2: } \\
\text { I RM bench } \\
\text { Press and } \\
\text { Parallel Squat } \\
\left(45^{\circ}\right) \\
\text { Session } 3 \text { : } \\
\text { I RM Military } \\
\text { Press and } \\
\text { deadlift }\end{array}$ \\
\hline
\end{tabular}


ARAVENA-SAGARDIA, P.; GARCÍA-SANDOVAL, A.; BARRAMUÑO, M.; HERRERA-VALENZUELA, T; MAGNANI, B. B. H; GUZMÁN-MUÑOZ, E.; LÓPEZ-FUENZALIDA, A.; CERDA, V. E. \& VALDÉS-BADILLA, P. Effects of intra-set rest on morphological variables, maximal strength and jump performance in university students. Int. J. Morphol., 39(1):274-281, 2021.

Table I. Effects of the intervention on morphological variables in university students.

\begin{tabular}{|c|c|c|c|c|c|c|}
\hline & & $\begin{array}{c}\text { Pre-test } \\
\text { Mean (SD) }\end{array}$ & $\begin{array}{c}\text { Post-test } \\
\text { Mean (SD) }\end{array}$ & value $p$ & Change $(\%)$ & $\operatorname{ES}(95 \%)$ \\
\hline Body & $\mathrm{CG}(\mathrm{n}=8)$ & $66.47(8.83)$ & $66.81(9.35)$ & 0.000 & 0.512 & $0.037(59.09-74.63)$ \\
\hline \multirow{2}{*}{$\begin{array}{l}\text { Weight } \\
(\mathrm{kg})\end{array}$} & EG $1(n=8)$ & $69.72(8.34)$ & $69.97(7.67)$ & 0.000 & 0.359 & $0.031(63.30-75.87)$ \\
\hline & EG $2(n=7)$ & $64.88(9.39)$ & $65.54(9.46)$ & 0.000 & 1.017 & $0.070(56.19-74.29)$ \\
\hline \multirow{3}{*}{$\begin{array}{c}\text { BMI } \\
\left(\mathrm{kg} / \mathrm{m}^{2}\right)\end{array}$} & $\mathrm{CG}(\mathrm{n}=8)$ & $23.46(1.42)$ & $23.56(1.44)$ & 0.000 & 0.426 & $0.070(22.27-24.77)$ \\
\hline & EG $1(n=8)$ & $24.41(1.99)$ & $24.51(1.74)$ & 0.000 & 0.410 & $0.053(22.88-25.85)$ \\
\hline & EG $2(n=7)$ & $22.35(2.37)$ & $22.56(2.18)$ & 0.000 & -3.383 & $0.347(20.15-24.58)$ ฯ \\
\hline \multirow{3}{*}{$\begin{array}{l}\text { Fat } \\
\text { mass } \\
(\%)\end{array}$} & $\mathrm{CG}(\mathrm{n}=8)$ & $29.16(5.42)$ & $27.27(4.89)$ & 0.000 & -6.481 & $0.366(24.62-31.36)$ व \\
\hline & EG $1(n=8)$ & $30.29(6.98)$ & $28.53(7.27)$ & 0.000 & -5.810 & $0.247(24.91-34.12)$ \\
\hline & EG $2(n=7)$ & $27.70(5.44)$ & $27.33(5.50)$ & 0.003 & -1.336 & $0.068(22.67-32.42)$ \\
\hline \multirow{3}{*}{$\begin{array}{c}\text { Muscle } \\
\text { mass } \\
(\%)\end{array}$} & $\mathrm{CG}(\mathrm{n}=8)$ & $42.56(3.82)$ & $44.01(3.58)$ & 0.002 & 3.407 & $0.392(39.37-47.00)$ \\
\hline & EG $1(n=8)$ & $43.18(4.91)$ & $45.08(5.49)$ & 0.000 & 4.400 & 0.365 (39.4-49.30) \\
\hline & EG $2(n=7)$ & $42.82(4.57)$ & $43.53(4.64)$ & 0.106 & 1.658 & $0.154(38.59-47.83)$ \\
\hline
\end{tabular}

CG: control group; EG1: experimental group 1; EG2: experimental group 2; SD: standard deviation; CI: confidence interval; BMI: body mass index; ES: effect size. II = small effect.

Table II. Effects of intervention on maximal strength and jump performance in university students.

\begin{tabular}{|c|c|c|c|c|c|c|}
\hline & & $\begin{array}{c}\text { Pre-test } \\
\text { Mean (SD) }\end{array}$ & $\begin{array}{l}\text { Post-test } \\
\text { Mean (SD) }\end{array}$ & Value $p$ & $\begin{array}{c}\text { Change } \\
(\%)\end{array}$ & ES (CI 95\%) \\
\hline \multirow{3}{*}{$\begin{array}{l}\text { Bench press } \\
(\mathrm{kg})\end{array}$} & $\mathrm{CG}(\mathrm{n}=8)$ & $46.00(15.61)$ & $55.87(17.09)$ & 0.001 & 21.46 & $0.60(32.94-70.16)^{\circ}$ \\
\hline & EG $1(n=8)$ & $54.11(25.74)$ & $60.77(26.85)$ & 0.000 & 12.31 & $0.25(34.32-81.41) \Phi$ \\
\hline & EG $2(n=7)$ & 47.85 (21.59) & $59.85(19.82)$ & 0.003 & 25.79 & $0.59(27.88-78.19)^{\circ}$ \\
\hline \multirow{3}{*}{$\begin{array}{l}\text { Military press } \\
\qquad(\mathrm{kg})\end{array}$} & $\mathrm{CG}(\mathrm{n}=8)$ & $33.37(14.18)$ & $40.00(12.86)$ & 0.004 & 19.87 & $0.49(21.51-158.62) \rrbracket$ \\
\hline & EG $1(n=8)$ & $36.33(16.66)$ & $44.77(14.57)$ & 0.000 & 23.23 & $0.54(23.52-50.75)^{\circ}$ \\
\hline & EG $2(n=7)$ & $34.14(12.72)$ & $39.57(14.29)$ & 0.001 & 15.91 & $0.40(22.37-55.98)$ व \\
\hline \multirow{3}{*}{$\begin{array}{l}\text { Parallel squat } \\
\left(45^{\circ}\right)(\mathrm{kg})\end{array}$} & $\mathrm{CG}(\mathrm{n}=8)$ & $65.25(16.55)$ & $101.00(25.84)$ & 0.015 & 54.79 & $1.65(50.4-122.6) \dagger$ \\
\hline & EG $1(n=8)$ & $71.44(33.73)$ & $98.44(29.67)$ & 0.000 & 37.79 & $0.85(45.51-121.25) \dagger$ \\
\hline & EG $2(n=7)$ & $68.00(26.61)$ & $101.14(37.55)$ & 0.002 & 48.74 & $1.02(43.38-135.87) \dagger$ \\
\hline \multirow{3}{*}{$\begin{array}{l}\text { Deadlift } \\
\quad(\mathrm{kg})\end{array}$} & $\mathrm{CG}(\mathrm{n}=8)$ & $94.12(23.49)$ & $113.00(37.00)$ & 0.007 & 20.06 & $0.61(74.48-112.6)^{\circ}$ \\
\hline & EG $1(n=8)$ & $106.66(36.68)$ & $125.00(39.45)$ & 0.001 & 17.19 & $0.48(78.47-143.93) \rrbracket$ \\
\hline & EG $2(n=7)$ & $102.28(46.62)$ & $116.57(45.46)$ & 0.000 & 13.97 & $0.31(59.16-155.66)$ \\
\hline \multirow{3}{*}{$\begin{array}{l}\text { CMJ } \\
(\mathrm{cm})\end{array}$} & $\mathrm{CG}(\mathrm{n}=8)$ & $0.35(0.06)$ & $0.38(0.05)$ & 0.007 & 8.57 & $0.54(0.29-0.43)^{\circ}$ \\
\hline & EG $1(n=8)$ & $0.37(0.09)$ & $0.41(0.12)$ & 0.007 & 10.81 & $0.38(0.3-0.50)$ \\
\hline & EG $2(n=7)$ & $0.38(0.10)$ & $0.39(0.10)$ & 0.059 & 2.63 & $0.10(0.28-0.490)$ \\
\hline
\end{tabular}

CMJ: countermovement jump; SD: standard deviation; ES: effect size. CG: control group; EG1: experimental group 1; EG2: experimental group 2; CI: confidence interval. II $=$ small effect; ${ }^{\circ}=$ moderate effect; $\dagger=$ strong effect.

\section{DISCUSSION}

This study aimed to analyze the effects of different intra-set rest after eight weeks of resistance training on morphological variables, maximal strength, and jump performance in physically active university students. The main result indicates that, regardless of the rest protocol used, similar benefits were achieved in morphological variables, maximal strength, and jump performance. This background reinforces previous research findings stating that cluster sets protocols achieve the same performance on muscle strength and benefits on morphological variables as traditional resistance training protocols (Mayo et al., 2014; Tufano et al., 2017, 2019). Besides this context, evidence showed that intra-set rest reduce the level of muscle fatigue, keeping the working speed, and decreasing the perceived effort (Ho et al., 2019; Latella et al.; García-Ramos et al.).

All three groups increased their BMI and muscle mass percentage significantly while showing a decrease in body fat percentage. Although few studies refer to these variables, similar results were seen in university students after 12 weeks of training, who increased their BMI and muscle mass percentage and reduced the body fat percentage (Crombie et al., 2012). While other studies only showed a significant increase in the muscle mass percentage (Oliver 
ARAVENA-SAGARDIA, P.; GARCÍA-SANDOVAL, A.; BARRAMUÑO, M.; HERRERA-VALENZUELA, T.; MAGNANI, B. B. H.; GUZMÁN-MUÑOZ, E.; LÓPEZ-FUENZALIDA, A.; CERDA, V. E. \& VALDÉS-BADILLA, P. Effects of intra-set rest on morphological variables, maximal strength and jump performance in university students. Int. J. Morphol., 39(1):274-281, 2021.

et al., 2013; Iglesias-Soler et al.). The BMI increase in intervened students is considered favorable due to the changes observed in muscle and fat mass, since the greater the muscle mass, the lower the risk of future sarcopenia (Padilla Colón et al., 2014). Moreover, it has been shown that, like the traditional resistance training protocols, the cluster sets protocols, exhibit an increased secretion of growth hormone and cortisol (Oliver et al., 2013; Girman et al., 2014; Iglesias-Soler et al.), which are essential facts for muscle reconstruction and protein synthesis. This, in turn, could explain the reported muscle mass increased percentage of the students in our study (Donnelly et al., 2009).

The maximum upper body strength (bench press and military press) improved significantly for all three groups after eight-week of intervention. This is a significant outcome since the intra-set rest used in our intervention (every 2 and 5 repetitions) could improve the technical execution of the exercises, as it has been reported in previous studies (GarcíaRamos et al.). On the other hand, it has been suggested that when intensity, volume, and recovery time are equal, there is a positive relationship between exercise and perceived effort (Mayo et al.), these elements would favor the adaptation to training. Meanwhile, Schoenfeld et al. pointed out that 3-minute rest at the end of the series would produce a more significant increase of maximal strength and muscle mass, than 1-minute rest in trained men. Therefore, the intraset rest used in our intervention could be as effective as those taken only at the end of the series.

Regarding the maximal strength of the lower body (parallel squat $\left(45^{\circ}\right.$ ) and deadlift), all three intervened groups significantly improved their 1RM. A similar investigation reported a better response about the maximal strength of the lower body when intra-set rest of $17.4 \mathrm{~s}$ were performed instead of rest at the end of the series (Iglesias-Soler et al.). Other benefits highlighted by the use of cluster sets protocols include: improvements in execution speed and output power for the parallel squat (Oliver et al., 2013); reduction of muscle fatigue for deep squats with intra-set rest of 10 and $20 \mathrm{~s}$ (Mora-Custodio et al.); increased efficiency for the deadlift impulse phase, increased muscle strength and hypertrophy with intra-set rest of $30 \mathrm{~s}$ (Moir et al., 2013), and reduced time for the 20-meter test with intra-set rest of $30 \mathrm{~s}$ (Nickerson et al., 2018). These facts, together, strengthen the use of cluster sets protocols to introduce young people to resistance training.

The jump performance improved for all three groups; however, the change was more significant for the CG and the EG1. Previous studies showed an improvement in this ability with cluster sets protocols (Girman et al.; Moreno et al., 2014; Nickerson et al., 2019). This situation agrees with
Kaynak et al. (2019) statement, which indicates that when the maximum force of the lower train improves, there is also an increase in jumping, due to the greater stimulation of the secondary mechanoreceptors involved in the work with loads, which produces an increase of joint forces and muscular contractions. On the other hand, Moreno et al., stated that jumps improved when fewer repetitions with intra-set rest fluctuating between 27 and $45 \mathrm{~s}$ were performed. This happens because fatigue is attenuated, allowing a higher concentric load than successive jumps. Despite the above, the improvements exhibited by the intervened students were attributed to the maximum force increase of the lower body since the exercises programmed in our study did not include multi-jumps.

Among the research strengths are a) the experimental design of the study, as well as the participants' randomization, which increased the internal consistency; b) the training planning, which considered a progression of the equivalent load in volume, intensity and total recovery time, and, at the same time, the systematization according to the participants' initial evaluations. While the main limitations were: a) failure to control feeding, which could influence morphological variables, b) failure to control sleeping of participants, which could affect maximal strength and jump performance assessments, c) inclusion of men and women in the experimental groups, which could reduce the specificity of results. In this sense, it was suggested conducting studies with larger samples and groups separated by sex.

This study strengthens the scientific evidence regarding the cluster sets protocols' benefits on muscle strength and hypertrophy in people performing resistance training (Schoenfeld et al.; Tufano et al., 2017, 2019). However, 2-minute rest at the end of the series should be considered to achieve the best response in people with experience in this kind of resistance training (Grgic et al.). Therefore, it is relevant to know the experience level of people who participate in resistance training programs, since different rest times could influence their performance (García-Ramos et al.), and this is an essential element when planning, systematizing and dosing the training load.

In conclusion, there are no significant changes between different intra-set rest when using the same volume, intensity and total recovery time during the exercise series in an intervention based on resistance training; thereby there is an equivalent increase in muscle mass, maximal strength, jump performance, as well as a fat mass reduction. Therefore, we recommend the use of intra-set rest in university students starting the resistance training if they are familiar with the PA practice. 
ARAVENA-SAGARDiA, P.; GARCÍA-SANDOVAL, A.; BARRAMUÑO, M.; HERRERA-VALENZUELA, T.; MAGNANI, B. B. H.; GUZMÁN-MUÑOZ, E.; LÓPEZFUENZALIDA, A.; CERDA, V. E. \& VALDÉS-BADILLA, P. Efectos del descanso intra-serie sobre variables morfológicas, fuerza máxima y saltabilidad en estudiantes universitarios. Int. J. Morphol., 39(1):274-281, 2021.

RESUMEN: La dosificación adecuada de ejercicios de resistencia muscular permite favorecer adaptaciones físicas y fisiológicas, y reducir lesiones. El objetivo de este estudio fue analizar los efectos de distintos tiempos de descanso intra-serie luego de ocho semanas de ejercicios de resistencia muscular sobre variables morfológicas, fuerza máxima y saltabilidad en estudiantes universitarios físicamente activos. Veinticinco estudiantes (15 hombres y 10 mujeres) fueron aleatorizados por sexo y distribuidos en: grupo control (GC) $(\mathrm{n}=8)$ con descanso sólo al final de la serie; grupo experimental $1(\mathrm{GE} 1)(\mathrm{n}=9)$ con un descanso intra-serie de $30 \mathrm{~s}$ y grupo experimental 2 (GE2) $(\mathrm{n}=8)$ con cuatro descansos intra-serie de $10 \mathrm{~s}$. Se midieron variables morfológicas [peso corporal, estatura bípeda, índice de masa corporal (IMC), masa adiposa y masa muscular], fuerza máxima del tren superior (press de banco plano y press militar) e inferior [sentadilla paralela $\left(45^{\circ}\right.$ ) y peso muerto] y saltabilidad con el salto contramovimiento (CMJ). Se obtuvo un aumento significativo $(\mathrm{p}<0,01)$ del peso corporal e IMC $\mathrm{y}$, una reducción significativa $(\mathrm{p}<0,01)$ de la masa adiposa en los tres grupos. La masa muscular aumentó significativamente $(\mathrm{p}<0,01)$ en el GC y GE1. La fuerza máxima del tren superior e inferior aumentaron significativamente $(\mathrm{p}<0,05)$ en los tres grupos y para todos los ejercicios, mientras que el CMJ aumentó significativamente en el GC y GE1. No existen diferencias significativas entre distintos tiempos de descanso intra-serie cuando se utiliza el mismo volumen, intensidad y descanso total durante las series de ejercicios, logrando un aumento equivalente en masa muscular, fuerza máxima, saltabilidad y reducción de la masa adiposa.

PALABRAS CLAVE: Antropometría; Fuerza muscular; Ejercicio físico; Entrenamiento de la fuerza.

\section{REFERENCES}

Bosco, C.; Luhtanen, P. \& Komi, P. A simple method for measurement of mechanical power in jumping. Eur. J. Appl. Physiol., 50(2):273-82, 1983.

Cohen, J. A power primer. Psychol. Bull., 112(1):155-9, 1992.

Crombie, A.; Liu, P.; Ormsbee, M. \& Ilich, J. Weight and body-composition change during the college freshman year in male general-population students and army Reserve Officer Training Corps (ROTC) cadets. Int. J. Sport Nutr. Exerc. Metab., 22(6):412-21, 2012.

Donnelly, J. E.; Blair, S. N.; Jakicic, J. M.; Manore, M. M.; Rankin, J. W.; Smith, B. K. \& American College of Sports Medicine. American College of Sports Medicine Position Stand. Appropriate physical activity intervention strategies for weight loss and prevention of weight regain for adults. Med. Sci. Sports Exerc., 41(2):459-71, 2009.

Garber, C. E.; Blissmer, B.; Deschenes, M. R.; Franklin, B. A.; Lamonte, M. J.; Lee, I. M.; Nieman D. C.; Swain, D. P. \& American College of Sports Medicine. American College of Sports Medicine position stand.
Quantity and quality of exercise for developing and maintaining cardiorespiratory, musculoskeletal, and neuromotor fitness in apparently healthy adults: guidance for prescribing exercise. Med. Sci. Sports Exerc., 43(7):1334-59, 2011.

García-Ramos, A.; González-Hernández, J.; Baños-Pelegrín, E.; CastañoZambudio, A.; Capelo-Ramírez, F.; Boullosa, D. \& Jiménez-Reyes, P. Mechanical and metabolic responses to traditional and cluster set configurations in the bench press exercise. J. Strength Cond. Res., 34(3):663-70, 2020.

Girman, J. C.; Jones, M T..; Matthews, T. D. \& Wood, R. J. Acute effects of a cluster-set protocol on hormonal, metabolic and performance measures in resistance-trained males. Eur. J. Sport Sci., 14(2):151-9, 2014.

Goessler, K. F. \& Polito, M. D. Effect of fixed and self-suggested rest intervals between sets of resistance exercise on post-exercise cardiovascular behavior. Rev. Bras. Cineantropom. Desempenho Hum., 15(4):467-75, 2013

Grgic, J.; Lazinica, B.; Mikulic, P.; Krieger, J. W. \& Schoenfeld, B. J. The effects of short versus long inter-set rest intervals in resistance training on measures of muscle hypertrophy: A systematic review. Eur. J. Sport Sci., 17(8):983-93, 2017.

Haff, G.; Burgess, S. J. \& Stone M. H. Cluster training: theoretical and practical applications for the strength and conditioning professional. UK Strength Cond. Assoc., 12:12-25, 2008.

Hardee, J. P.; Triplett, N. T.; Utter, A. C.; Zwetsloot, K. A. \& Mcbride, J. M. Effect of interrepetition rest on power output in the power clean. $J$. Strength Cond. Res., 26(4):883-9, 2012.

Haskell, W. L.; Lee, I. M.; Pate, R. R.; Powell, K. E.; Blair, S. N.; Franklin, B. A.; Macera, C. A.; Heath, G. W.; Thompson, P. D. \& Bauman, A. Physical activity and public health: updated recommendation for adults from the American College of Sports Medicine and the American Heart Association. Med. Sci. Sports Exerc., 39(8):1423-34, 2007.

Ho, I. M. K.; Luk, J. T. C.; Ngo, J. K. \& Wong, D. P. Effects of different intraset rest durations on lifting performance and self-perceived exertion during bench press exercise. J. Strength Cond. Res., 2019. DOI: https:/ /www.doi.org/10.1519/JSC.0000000000003101

Iglesias-Soler, E.; Mayo, X.; Río-Rodríguez, D.; Carballeira, E.; Fariñas, J. \& Fernández-Del-Olmo, M. Inter-repetition rest training and traditional set configuration produce similar strength gains withou cortical adaptations. J. Sports Sci., 34(15):1473-84, 2016.

Kaynak, H.; Altun, M. \& Tok, S. Effect of force sense to active joint position sense and relationships between active joint position sense, force sense, jumping and muscle strength. J. Mot. Behav., 52(3):342-51, 2019.

Latella, C.: Teo, W. P.; Drinkwater, E. J.; Kendall, K. \& Haff, G. G. The acute neuromuscular responses to cluster set resistance training: a systematic review and meta-analysis. Sports Med., 49(12):1861-77, 2019 .

Marfell-Jones, M. J.; Stewart, A. D. \& de Ridder, J. H. International Standards for Anthropometric Assessment. Wellington, International Society for the Advancement of Kinanthropometry, 2012.

Mayo, X.; Iglesias-Soler, E. \& Fernández-Del-Olmo, M. Effects of set configuration of resistance exercise on perceived exertion. Percept. Mot. Skills, 119(3):825-37, 2014.

Ministerio de Salud (MINSAL). Encuesta Nacional de Salud 2016-2017. Primeros Resultados. Santiago de Chile, Departamento de Epidemiología, División de Planificación Sanitaria, Subsecretaría de Salud Pública, Ministerio de Salud, Gobierno de Chile, 2017. Available from: https://redsalud.ssmso.cl/wp-content/uploads/2018/02/ENS2016-17_PRIMEROS-RESULTADOS-ilovepdf-compressed.pdf

Moir, G. L.; Graham, B. W.; Davis, S. E.; Guers, J. J. \& Witmer, C. A. Effect of cluster set configurations on mechanical variables during the deadlift exercise. J. Hum. Kinet., 39:15-23, 2013.

Mora-Custodio, R.; Rodríguez-Rosell, D.; Yáñez-García, J. M.; SánchezMoreno, M.; Pareja-Blanco, F. \& González-Badillo, J. J. Effect of different inter-repetition rest intervals across four load intensities on velocity loss and blood lactate concentration during full squat exercise. J. Sports Sci., 36(24):2856-64, 2018. 
Moreno, S. D.; Brown, L. E.; Coburn, J. W. \& Judelson, D. A. Effect of cluster sets on plyometric jump power. J. Strength Cond. Res., 28(9):2424-8, 2014.

Nickerson, B. S.; Mangine, G. T.; Williams, T. D. \& Martinez, I. A. Effect of cluster set warm-up configurations on sprint performance in collegiate male soccer players. Appl. Physiol. Nutr. Metab., 43(6):625-30, 2018.

Nickerson, B. S.; Williams, T. D.; Snarr, R. L. \& Park, K. S. Individual and combined effect of inter-repetition rest and elastic bands on jumping potentiation in resistance-trained men. J. Strength Cond. Res., 33(8):2087-93, 2019.

Nóbrega, S. R. \& Libardi, C. A. Is resistance training to muscular failure necessary? Front. Physiol., 7:10, 2016.

Oliver, J. M.; Jagim, A. R.; Sanchez, A. C.; Mardock, M. A.; Kelly, K. A.; Meredith, H. J.; Smith, G. L.; Greenwood, M.; Parker, J. L.; Riechman, S. E.; et al. Greater gains in strength and power with intraset rest intervals in hypertrophic training. J. Strength Cond. Res., 27(11):311631, 2013.

Oliver, J. M.; Kreutzer, A.; Jenke, S.; Phillips, M. D.; Mitchell, J. B. \& Jones, M. T. Acute response to cluster sets in trained and untrained men. Eur. J. Appl. Physiol., 115(11):2383-93, 2015.

Padilla Colón, C. J.; Sánchez Collado, P. \& Cuevas, M. J. Beneficios del entrenamiento de fuerza para la prevención y tratamiento de la sarcopenia. Nutr. Hosp., 29(5):979-88, 2014.

Ritti-Dias, R. M.; Avelar, A.; Salvador, E. P. \& Cyrino, E. S. Influence of previous experience on resistance training on reliability of one-repetition maximum test. J. Strength Cond. Res., 25(5):1418-22, 2011.

Ross, W. D. \& Kerr, D. A. Fraccionamiento de la Masa Corporal: Un Nuevo Método para Utilizar en Nutrición, Clínica y Medicina Deportiva. PubliCE, 1993. Available from: https://g-se.com/fraccionamiento-de-la-masa-corporal-un-nuevo-metodo-para-utilizar-en-nutricionclinica-y-medicina-deportiva-261-sa-Q57cfb27120415

Schoenfeld, B. J. The mechanisms of muscle hypertrophy and their application to resistance training. J. Strength Cond. Res., 24(10):285772, 2010.

Schoenfeld, B. J.; Pope, Z. K.; Benik, F. M.; Hester, G. M.; Sellers, J.; Nooner, J. L.; Schnaiter, J. A.; Bond-Williams, K. E.; Carter, A. S.; Ross, C. L.; et al. Longer interset rest periods enhance muscle strength and hypertrophy in resistance-trained men. J. Strength Cond. Res., 30(7):1805-12, 2016.

Suchomel, T. J.; Nimphius, S. \& Stone, M. H. The importance of muscular strength in athletic performance. Sports Med., 46(10):1419-49, 2016.

Tufano, J. J.; Brown, L. E. \& Haff, G. G. Theoretical and practical aspects of different cluster set structures: a systematic review. J. Strength Cond. Res., 31(3):848-67, 2017.

Tufano, J. J.; Conlon, J. A.; Nimphius, S.; Oliver, J. M.; Kreutzer, A. \& Haff, G. G. Different cluster sets result in similar metabolic, endocrine, and perceptual responses in trained men. J. Strength Cond. Res., 33(2):346-54, 2019.

World Medical Association. Declaración de Helsinki de la AMM. Principios éticos para las investigaciones médicas en seres humanos. FerneyVoltaire, World Medical Association, 2019. Available from: http:// repositorio.mederi.com.co/bitstream/handle/123456789/386/ Declaracion-Helsinki-2013-Esp.pdf?sequence $=1$

\author{
Corresponding author: \\ Pablo Antonio Valdés Badilla \\ Universidad Autónoma de Chile \\ Av. Alemania 01090 \\ Temuco \\ CHILE
}

Email: pablo.valdes@uautonoma.cl

Received: 26-05-2020

Accepted: 07-09-2020 